\begin{tabular}{|c|c|c|c|}
\hline \multirow{3}{*}{$\begin{array}{r}\text { Case Reports in } \\
\text { Gastroenterology }\end{array}$} & \multirow{2}{*}{\multicolumn{2}{|c|}{ Case Rep Gastroenterol 2017;11:675-679 }} & \multirow[b]{3}{*}{$\begin{array}{l}\text { Karger } \\
\text { Open access }\end{array}$} \\
\hline & & & \\
\hline & $\begin{array}{l}\text { DOI: } 10.1159 / 000481165 \\
\text { Publisned onlIne: November 9, } 2017\end{array}$ & $\begin{array}{l}\text { ○ } 2017 \text { The Author(s) } \\
\text { Published by S. Karger AG, Basel } \\
\text { www.karger.com/crg }\end{array}$ & \\
\hline & $\begin{array}{l}\text { This article is licensed under the } \\
\text { International License (CC BY-NC) (h } \\
\text { Usage and distribution for commercia }\end{array}$ & $\begin{array}{l}\text { mons Attribution-NonCommercial } 4.0 \\
\text { rger.com/Services/OpenAccessLicense). } \\
\text { quires written permission. }\end{array}$ & \\
\hline
\end{tabular}

\title{
Listeria Monocytogenes Brain Abscess in Crohn's Disease Treated with Adalimumab
}

\author{
Amporn Atsawarungruangkit Fernando Dominguez Gustavo Borda \\ Nikolaos Mavrogiorgos \\ MetroWest Medical Center, Framingham, MA, USA
}

\section{Keywords}

Listeria monocytogenes · Brain abscess · Crohn's disease · Adalimumab

\begin{abstract}
Listeria monocytogenes is a gram-positive bacterium that causes listeriosis. Brain abscess is a very uncommon manifestation of listeriosis and has not been reported to be associated with adalimumab (humira), one of the approved medications for treating Crohn's disease. A 45year-old female with Crohn's disease presented with sudden onset of fever, headache, nausea, vomiting, and altered mental status for 1 day. She was on prednisone and 6 -mercaptopurine. She had started taking adalimumab 17 days prior to admission. She had signs of toxicity, confusion, and nuchal rigidity, but showed neither central nervous system deficits nor focal deficits. The laboratory results revealed Gram-positive coccobacillus, positive blood and cerebrospinal fluid culture for Listeria monocytogenes, and a $5 \times 5 \mathrm{~mm}$ ring-enhancing lesion of brain abscess on MRI. After holding off 6 -mercaptopurine and adalimumab, her mental status improved on the next day. Finally, she was discharged on day 7 of hospitalization with ampicillin $2 \mathrm{~g}$ intravenously every $4 \mathrm{~h}$ for a total of 2 weeks. Two weeks later, the followup MRI showed a 2-mm area of residual enhancement in the left temporal lobe at the site of the previous brain abscess. Adalimumab, as a tumor necrosis factor (TNF)-alpha inhibitor, carries a risk of triggering opportunistic infection, such as listeriosis. With an altered mental status or neurological signs in patients receiving TNF-alpha antagonizing agent, physicians should suspect bacterial infection in the central nervous system and promptly initiate treatment for brain abscess if needed.




\section{Introduction}

Listeria monocytogenes (LM), a gram-positive bacterium, is commonly found in food or water. Patients infected with LM usually have fever, muscle aches, and sometimes nausea or diarrhea. The common manifestations of listeriosis are meningitis, meningoencephalitis, and bacteremia in immunosuppressed patients. However, brain abscess is rarely found in patient with LM infection. On the other hand, adalimumab (humira), a recombinant human IgG1 monoclonal antibody directed against tumor necrosis factor (TNF), is one of the approved treatments for Crohn's disease [1]. There were a few reports about patients who developed brain abscess from LM infection [2,3]. To the best of our knowledge, there is no reported evidence of LM brain abscesses in patient treated with adalimumab. Herein, we present a patient with Crohn's disease who developed a left temporal lobe abscess within 17 days after adding adalimumab to her standing regimen of prednisone and 6-mercaptopurine.

\section{Case Report}

A 45-year-old female presented with sudden onset of fever, headache, nausea, vomiting, and altered mental status for 1 day. She had a past medical history of Crohn's disease. Additionally, she was on oral prednisone $30 \mathrm{mg}$ daily and oral 6-mercaptopurine $25 \mathrm{mg}$ daily. Seventeen days before admission, she had started taking adalimumab. On physical examination, the patient had a temperature of $39.8^{\circ} \mathrm{C}$, blood pressure of $133 / 94 \mathrm{~mm} \mathrm{Hg}$, heart rate of 122 beats/min, respiratory rate of 20 breaths/min, and oxygen saturation of $20 \%$ in room air. Apart from that, she had signs of toxicity, confusion, and nuchal rigidity. Due to the patient's discomfort, the tests for Kernig's sign and Brudzinski's sign were not performed.

A neurological examination revealed neither central nervous system (CNS) deficits nor focal deficits. For laboratory data, complete blood count was notable for leukocytosis of 12.7 $\mathrm{k} / \mathrm{mL}$ with bandemia (band neutrophils $15 \%$ ), hemoglobin $14.5 \%$, hematocrit $42.5 \mathrm{~g} / \mathrm{dL}$, and platelet count $151,000 / \mu \mathrm{L}$. Her comprehensive metabolic panel was remarkable for hyponatremia (serum sodium $132 \mathrm{mmol} / \mathrm{L}$ ), hypochloremia (chloride $87 \mathrm{mmol} / \mathrm{L}$ ), anion gap metabolic acidosis (anion gap $25 \mathrm{mmol} / \mathrm{L}$ and carbon dioxide $20 \mathrm{mmol} / \mathrm{L}$ ), lactic acidosis (lactic acid $2.53 \mathrm{mmol} / \mathrm{L}$ ), and hyperglycemia (glucose $142 \mathrm{mg} / \mathrm{dL}$ ). By lumbar puncture we could extract $1.5 \mathrm{~mL}$ of turbid cerebrospinal fluid (CSF); CSF analysis showed white blood cell count 2,300 cells/mL (48\% segmented neutrophils, $6 \%$ lymphocytes, and $43 \%$ monocytes), red blood cell count 130 cells/mL, glucose $44 \mathrm{mg} / \mathrm{dL}$, and protein $216 \mathrm{mg} / \mathrm{dL}$. CSF stain revealed Gram-positive coccobacilli, the patient was given vancomycin, ceftriaxone, and ampicillin. At the same time, 6-mercaptopurine and adalimumab were discontinued immediately together with tapering off prednisone. Consequently, the patient's mental status improved on the next day despite persistent headache and fever with a body temperature of $37.8^{\circ} \mathrm{C}$. Since both blood and CSF culture were positive for LM, vancomycin and ceftriaxone were hence discontinued; the patient eventually defervesced.

Then, the initial MRI of the brain came back showing a $5 \times 5 \mathrm{~mm}$ ring-enhancing lesion in the left temporal lobe with surrounding increased T2 and FLAIR signal consistent with brain abscess (Fig. 1). The patient was discharged on day 7 of hospitalization with ampicillin $2 \mathrm{~g}$ intravenously every $4 \mathrm{~h}$ for a total of 2 weeks. The follow-up MRI at 2 weeks after the initial treatment of ampicillin revealed decreasing signs of a ring-enhancing lesion in the left temporal lobe (Fig. 2). After completing 3 weeks of ampicillin, the patient received an additional week of trimethoprim/sulfamethoxazole $10 \mathrm{mg} / \mathrm{kg} /$ day. A repeat MRI of the brain 


\section{Case Reports in Gastroenterology}

Case Rep Gastroenterol 2017;11:675-679

\begin{tabular}{l|l}
\hline DOI: $10.1159 / 000481165$ & $\odot 2017$ The Author(s). Published by S. Karger AG, Basel \\
\hline
\end{tabular} www.karger.com/crg

Atsawarungruangkit et al.: Listeria Monocytogenes Brain Abscess in Crohn's Disease Treated with Adalimumab

was performed 4 weeks after the initial treatment, showing no evidence of a ring-enhancing lesion in the left temporal lobe (Fig. 3).

\section{Discussion}

LM is one of the most harmful food-borne pathogens, as the Center for Disease Control estimates that listeriosis causes approximately 1,600 illnesses and 260 deaths per year in the United States [4]. As an intracellular organism, LM can invade tissues normally resistant to infection, such as the CNS, the gravid uterus, or a fetus [5]. Thus, cellular immune response plays an important role for protective immunity against LM; any conditions or medications associated with impaired cellular immunity may prone to LM infection [3].

Brain abscess accounts for approximately $10 \%$ of CNS infections by LM [6]. The diagnosis of LM brain abscess may be suspected from the clinical findings. However, there is no clinical method to separate LM brain abscess from other infectious diseases that can lead to fever, constitutional symptoms, headache, and focal neurological deficits. For this reason, a positive blood or CSF culture is required for a definite diagnosis. However, there was a report that patients with LM brain abscess were tested positive for LM based on blood culture in $79 \%$ and CSF culture in $23 \%$ of all cases [3].

In this case, the patient had started taking adalimumab, a TNF-alpha inhibitor, as a treatment for Crohn's disease. Consequently, adalimumab suppressed the inflammatory response, which led to listeriosis. In 2011, the risk of developing listeriosis from TNF-alpha inhibitors was added to the drug label according the US Food and Drug Administration [7]. It is also worth noting that most patients who developed these infections were taking concomitant immunosuppressants, such as methotrexate or corticosteroids [7, 8]. A recent review article identified 26 cases of LM infection associated with adalimumab: $36 \%$ were CNS infections (i.e., meningitis or encephalitis) and $90 \%$ were taking concomitant immunosuppressants (i.e., steroid, methotrexate, or azathioprine) [8]. To the best of our knowledge, there is no reported evidence of LM brain abscess in patients following adalimumab therapy. Yet, right thalamus cerebral toxoplasmosis was reported in a 67-year-old man with rheumatoid arthritis who underwent treatment with adalimumab [9].

Unlike other reported incidences, this patient developed LM brain abscess at the left temporal lobe 17 days after adding adalimumab to a standing regimen of prednisone and 6mercaptopurine. Although the patient carried a risk for brain abscess from prednisone and 6-mercaptopurine, she had never been reported to have brain abscess before. The addition of adalimumab could have accelerated a serious opportunistic infection such as LM brain abscess. We strongly encourage physicians to maintain a high level of suspicion of listeriosis in patients, who are on a TNF-alpha antagonizing agent, with an altered mental status or neurological signs and promptly initiate treatment for brain abscess if needed.

\section{Statement of Ethics}

The authors have no ethical conflicts to disclose. 


\section{Case Reports in Gastroenterology}

Atsawarungruangkit et al.: Listeria Monocytogenes Brain Abscess in Crohn's Disease Treated with Adalimumab

\section{Disclosure Statement}

There are no financial disclosures for any of the authors.

\section{References}

1 Lichtenstein GR, Hanauer SB, Sandborn WJ; Practice Parameters Committee of American College of Gastroenterology: Management of Crohn's disease in adults. Am J Gastroenterol. 2009;104:465-483; quiz 464, 484.

2 Eckburg PB, Montoya JG, Vosti KL: Brain abscess due to Listeria monocytogenes: five cases and a review of the literature. Medicine (Baltimore). 2001;80:223-235.

-3 Limmahakhun S, Chayakulkeeree M: Listeria monocytogenes brain abscess: two cases and review of the literature. Southeast Asian J Trop Med Public Health 2013;44:468-478.

4 Centers for Disease Control and Prevention: Listeria (Listeriosis). www.cdc.gov/Listeria/statistics.html (accessed: July 30, 2016).

5 Gellin BG, Broome CV: Listeriosis. JAMA 1989;261:1313-1320.

6 Lorber B: Listeriosis. Clin Infect Dis 1997;24:1-9; quiz 10-11.

7 US Food \& Drug Administration. FDA Drug Safety Communication: Drug labels for the Tumor Necrosis Factor-alpha (TNF $\alpha$ ) blockers now include warnings about infection with Legionella and Listeria bacteria. www.fda.gov/Drugs/DrugSafety/ucm270849.htm (accessed: July 30, 2017).

8 Bodro M, Paterson DL: Listeriosis in patients receiving biologic therapies. Eur J Clin Microbiol Infect Dis 2013;32:1225-1230.

-9 Nardone R, Zuccoli G, Brigo F, Trinka E, Golaszewski S: Cerebral toxoplasmosis following adalimumab treatment in rheumatoid arthritis. Rheumatology (Oxford) 2014;53:284.

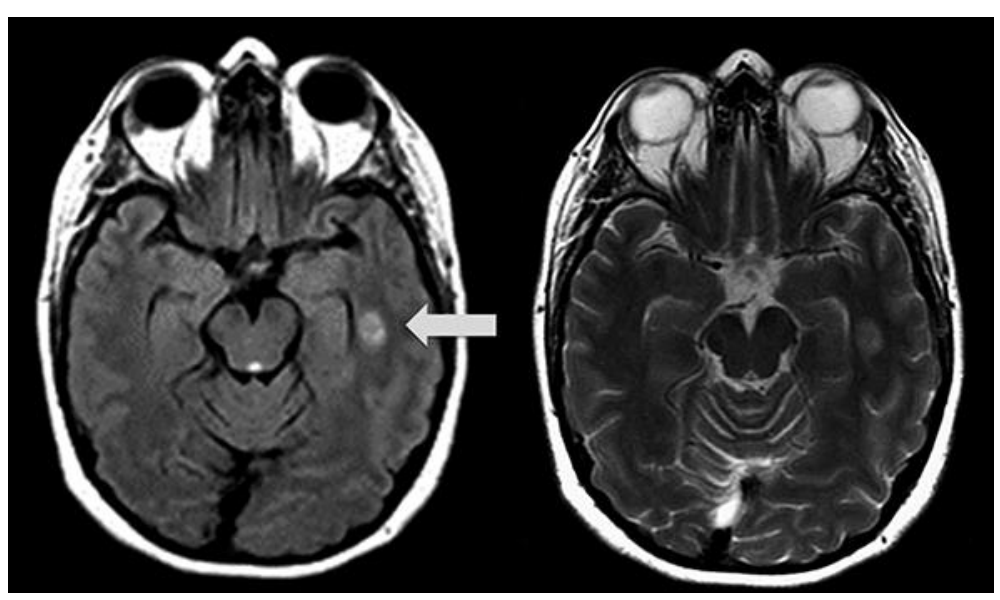

Fig. 1. MRI brain on admission day showing a $5 \times 5 \mathrm{~mm}$ ring-enhancing lesion in the left temporal lobe. 


\section{Case Reports in Gastroenterology

\begin{tabular}{l|l}
\hline Case Rep Gastroenterol 2017;11:675-679 \\
\hline DOI: 10.1159/000481165 & $\begin{array}{l}\text { @ 2017 The Author(s). Published by S. Karger AG, Basel } \\
\text { www.karger.com/crg }\end{array}$ \\
\hline
\end{tabular} \\ Atsawarungruangkit et al.: Listeria Monocytogenes Brain Abscess in Crohn's Disease Treated with Adalimumab}

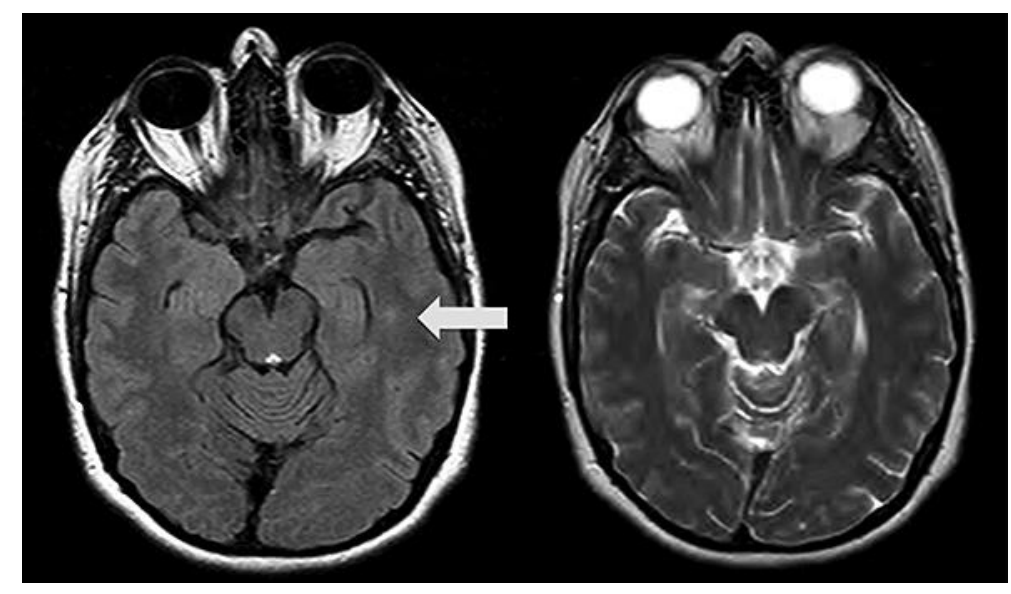

Fig. 2. MRI brain at 2 weeks after treatment showing decreasing signs of a ring-enhancing lesion in the left temporal lobe.

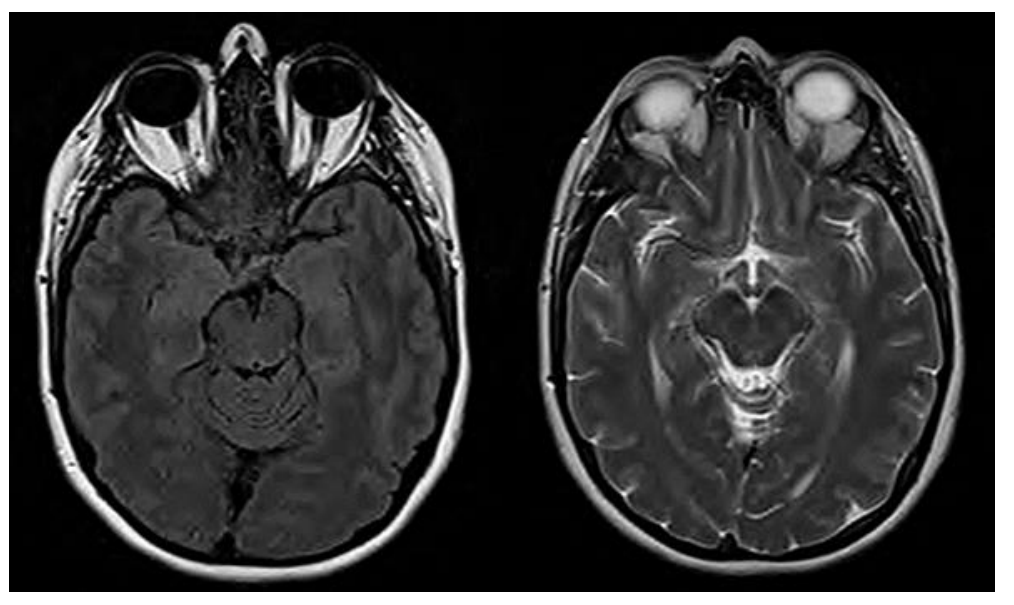

Fig. 3. MRI brain at 4 weeks after treatment showing no evidence of a ring-enhancing lesion in the left temporal lobe. 